\title{
PENINGKATAN HASIL BELAJAR SISWA PADA MATA PELAJARAN ILMU PENGETAHUAN ALAM TENTANG GAYA DAN FUNGSINYA DENGAN MENGGUNAKAN MODEL PEMBELAJARAN KOOPERATIF TIPE MAKE A MATCH
}

\author{
Yayan Rahmayantia ${ }^{*}$ \\ ${ }^{a)}$ SD Negeri Bantarjati 8, Bogor, Indonesia \\ *e-mail korespondensi : yayan.rahmayanti@gmail.com
}

\begin{abstract}
Abstrak. Penelitian ini bertujuan (1) Untuk mengetahui model pembelajaran kooperatif tipe Make a Match dapat meningkatkan hasil belajar peserta didik pada mata pelajaran Ilmu Pengetahuan Alam tentang gaya dan fungsinya di kelas V SD Negeri Bantarjati 7 Kecamatan Bogor Utara Kota Bogor semester 2. (2) Untuk mendeskripsikan proses peningkatan hasil belajar peserta didik pada mata pelajaran Ilmu Pengetahuna Alam tentang gaya dan fungsinya sebelum dan sesudah menggunakan model pembelajaran kooperatif tipe Make a Match di kelas V SD Negeri Bantarjati 7 semester 2. (3) Untuk mengukur besarnya peningkatan hasil belajar peserta didik pada mata pelajaran Ilmu Pengetahuna Alam tentang gaya dan fungsinya sesudah menggunakan model pembelajaran kooperatif tipe Make a Match di kelas V SD Negeri Bantarjati 7. Hasil penelitian ini menunjukkan bahwa dengan menggunakan model pembelajaran kooperatif Tipe Make a Match dapat menjadi variasi pembelajaran yang menyenangkan bagi peserta didik sehingga terbukti meningkatkan hasil belajar peserta didik di Kelas V SD Negeri Bantarjati 7. Sebelum menggunakan model pembelajaran kooperatif Tipe Make a Match hasil belajar peserta didik hanya mencapai nilai rata-rata 62,25 kemudian terjadi peningkatan setelah menggunakan model pembelajaran kooperatif Tipe Make a Match menjadi 74,12 pada siklus 1 dan 79,125 pada siklus 2. Dari uraian di atas peneliti menyimpulkan bahwa penggunaan model pembelajaran kooperatif Tipe Make a Match yang disesuaikan dengan materi pembelajaran dapat menciptakan situasi belajar yang menyenangkan sehingga terjadi peningkatan hasil belajar peserta didik. Oleh karena itu peneliti menyarankan agar penggunaan model pembelajaran kooperatif Tipe Make a Match disosialisasikan dan digunakan sebagai alternatif dalam pembelajaran IPA di sekolah-sekolah di lingkungan Dinas Pendidikan Kota Bogor.
\end{abstract}

Kata Kunci: model pembelajaran kooperatif tipe Make a Match, gaya dan fungsinya

\section{IMPROVEMENT OF STUDENT LEARNING OUTCOMES IN NATURAL SCIENCE LESSONS LEARNING ABOUT THE FORCE AND FUNCTION BY USING THE LEARNING MODEL COOPERATIVE TYPE MAKE A MATCH}

Abstract. This study aims (1) To find out the Make a Match type of cooperative learning model can improve student learning outcomes in Natural Sciences about the force and function in class V SD Negeri Bantarjati 7, Bogor Utara, Bogor, semester 2 (2) describe the process of improving student learning outcomes in Natural Science subjects about their force and function before and after using the Make a Match type cooperative learning model in class V SD Negeri Bantarjati 7 (3) To measure the magnitude of the increase in student learning outcomes in Nature Science subjects about force and function after using the Make a Match cooperative learning model in class V of SD Negeri Bantarjati 7. The results of this study indicate that using the Make a Match cooperative learning model can be a fun variation of learning for students so that proven, men increase student learning outcomes in Class $\mathrm{V}$ Bantarjati State Elementary School 7. Before using the Make a Match type of cooperative learning model the learning outcomes of students only reached an average value of 62.25 then an increase occurred after using the Make a Match type cooperative learning model to 74, 12 in cycle 1 and 79.125 in cycle 2 . From the description above the researchers concluded that the use of a Make a Match type of cooperative learning model adapted to learning material can create a pleasant learning situation so that an increase in student learning outcomes. Therefore the researchers suggest that the use of the Make a Match type of cooperative learning model be socialized and used as an alternative in science learning in schools within the Bogor City Education Office.

Keywords: cooperative learning model type Make a Match, force and function.

\section{PENDAHULUAN}

Pendidikan adalah faktor yang paling penting dan prioritas utama yang membutuhkan perhatian serius dari semua pihak, karena pendidikan adalah penentu kemajuan bangsa di masa depan [1]. Tujuan dan cita-cita nasional, untuk kehidupan intelektual bangsa terkandung dalam UUD 1945. Pemerintah bersama masyarakat terus mencari pengembangan pendidikan demi terwujudnya bangsa yang mandiri, unggul dan siap menghadapi dunia globalisasi [2].
Proses belajar mengajar sesungguhnya bukanlah suatu proses yang mandiri atau hanya melibatkan satu variabel saja, akan tetapi proses pendidikan yang secara implisit menunjukkan partisipasi komplek yang melibatkan berbagai unsur diantaranya guru, murid, orang tua, pemerintah, dan masyarakat. Maka wajar jika kemudian jika pendidikan menjadi persoalan publik. Oleh karena itu menghilangkan salah satu fungsi dan komponen-komponen tersebut berakibat terhambatnya roda yang dijalankan oleh sebuah institusi pendidikan. Budaya sekolah di SD dapat 
diidentifikasikan dari setiap lapisan budaya sekolah yang terbagi dua yaitu lapisan yang dapat diamati dan lapisan yang tersembunyi atau lapisan yang tidak dapat diamati [3] Dalam pembelajaran IPA banyak guru yang mengeluhkan rendahnya kemampuan peserta didik dalam menerapkan konsep IPA. Hal ini terlihat dari banyaknya kesalahan peserta didik dalam memahami konsep pembelajaran sehingga mengakibatkan kesalahan-kesalahan dalam mengerjakan soal sehingga mengakibatkan rendahnya prestasi belajar peserta didik, baik dalam ulangan harian, ulangan semester, maupun ujian akhir sekolah, padahal dalam pelaksanaan proses pembelajaran di kelas biasanya guru memberikan tugas secara kontinu berupa latihan soal. Kondisi riil dalam pelaksanaannya latihan yang diberikan tidak sepenuhnya dapat meningkatkan kemampuan peserta didik dalam menerapkan pembelajaran IPA. Rendahnya mutu pembelajaran dapat diartikan kurang efektifnya proses pembelajaran. Penyebabnya dapat berasal dari peserta didik, guru maupun sarana dan prasarana yang ada, minat dan motivasi peserta didik yang rendah, kinerja guru yang rendah, serta sarana dan prasarana yang kurang memadai akan menyebabkan pembelajaran menjadi kurang efektif.

Dari permasalahan di atas maka guru akan mengubah pembelajaran tentang gaya dan fungsinya dengan menggunkan model pembelajaran kooperatif tipe Make a Match. Karena model ini menurut Lie [4] menyatakan bahwa model pembelajaran Make a Match merupakan teknik belajar yang memberi kesempatan peserta didik untuk bekerja sama dengan orang lain. Teknik pembelajaran kooperatif tipe Make a Match atau mencari pasangan. Salah satu keunggulan tehnik ini adalah peserta didik mencari pasangan sambil belajar mengenai suatu konsep atau topik dalam suasana yang menyenangkan. Menurut Sugiyanto [5] strategi belajar mencari pasangan (Make a Match) merupakan salah satu contoh pembelajaran kooperatif model struktural yang dikembangkan oleh Spencer Kagan. Salah satu keunggulan teknik ini adalah peserta didik mencari pasangan sambil belajar mengenai suatu konsep atau topik dalam bentuk soal-jawab dengan suasana yang menyenangkan, dapat digunakan dalam semua mata pelajaran dan semua tingkatan usia anak didik.

Melalui strategi mencari pasangan ini peserta didik dapat memperoleh pengalaman langsung, sehingga dapat menambah kekuatan untuk menerima, menyimpan, dan memproduksi kesan-kesan tentang hal-hal yang dipelajarinya. Dengan demikian peserta didik, terlatih untuk dapat menemukan sendiri berbagai konsep yang dipelajari secara holistik, bermakna, otentik, dan aktif. Cara pengemasan pengalaman belajar yang dirancang guru sangat berpengaruh terhadap kebermaknaan pengalaman bagi para peserta didik.

Pengalaman belajar lebih menunjukkan kaitan unsurunsur konseptual menjadikan proses pembelajaran lebih efektif. Kaitan konseptual yang dipelajari dengan sisi bidang kajian yang relevan akan membentuk skema atau konsep, sehingga peserta didik akan memperoleh keutuhan dan kebulatan pengetahuan, perolehan keutuhan belajar, pengetahuan, serta kebulatan pandangan tentang kehidupan dan dunia nyata dapat direfleksikan melalui strategi Make a Match.

Guna meningkatkan partisipasi dan keaktifan peserta didik dalam kelas, guru menerapkan model pembelajaran Make a Match. Model Make a Match atau mencari pasangan merupakan salah satu alternatif yang dapat diterapkan kepada peserta didik. Penerapan model ini dimulai dari teknik yaitu peserta didik disuruh mencari pasangan kartu yang merupakan jawaban/soal sebelum batas waktunya, peserta didik yang dapat mencocokkan kartunya diberi poin. Model pembelajaran Make a Match atau mencari pasangan dikembangkan oleh Lorna Curran [4]. Salah satu keunggulan tehnik ini adalah peserta didik mencari pasangan sambil belajar mengenai suatu konsep atau topik dalam suasana yang menyenangkan.

Proses merupakan prosedur pemecahan masalah melalui model ilmiah; model ilmiah meliputi pengamatan, penyusunan hipotesis, perancangan eksperimen, percobaan atau penyelidikan, pengujian hipotesis melalui eksperimen, evaluasi, pengukuran, dan penarikan kesimpulan. Beberapa ilmuwan memberikan definisi Ilmu Pengetahuan Alam sesuai dengan pengamatan dan pemahamannya. Carin [6] mendefinisikan science sebagai The activity of questioning and exploring the universe and finding and expressing it's hidden order, yaitu "Suatu kegiatan berupa pertanyaan dan penyelidikan alam semesta dan penemuan dan pengungkapan serangkaian rahasia alam”.

Ilmu Pengetahuan Alam adalah studi mengenai alam sekitar, dalam hal ini berkaitan dengan cara mencari tahu tentang alam secara sistematis, sehingga Ilmu Pengetahuan Alam bukan hanya penguasaan kumpulan pengetahuan yang berupa fakta-fakta, konsep-konsep, atau prinsip-prinsip saja, tetapi juga merupakan suatu proses penemuan.

Cain \& Evans [7] menyatakan bahwa Ilmu Pengetahuan Alam mengandung empat hal yaitu: konten atau produk, proses atau model, sikap, dan teknologi. Pendapat lain tentang Ilmu Pengetahuan Alam dikatakan oleh Agus [8] yang mengatakan bahwa sains adalah kumpulan pengetahuan dan cara-cara untuk mendapatkan dan mempergunakan pengetahuan itu. Sains merupakan produk dan proses yang tidak dapat dipisahkan. "Real Science is both product and process, inseparably Joint"

Ilmu Pengetahuan Alam sebagai konten dan produk mengandung arti bahwa di dalam Ilmu Pengetahuan Alam terdapat fakta-fakta, hukum-hukum, prinsip-prinsip, dan teori-teori yang sudah diterima kebenarannya. Ilmu Pengetahuan Alam diterapkan di sekolah karena memiliki kecenderungan bagi peserta didik, dimana hal ini sesuai dengan pernyataan dalam Strategi Pembelajaran MIPA [9] yang mengatakan bahwa kecenderungan pembelajaran Ilmu Pengetahuan Alam yang diterapkan di sekolah: 1) Pembelajaran hanya berorientasi pada tes/ ujian; 2) Pengalaman belajar yang diperoleh di kelas tidak utuh dan tidak berorientasi pada tercapainya standar kompetensi dan kompetensi dasar; 3) Pembelajaran lebih bersifat teachercentered, guru hanya menyampaikan IPA sebagai produk dan peserta didik menghafal informasi faktual; 4) Peserta didik hanya mempelajari IPA pada domain kognitif yang 
terendah, peserta didik tidak dibiasakan untuk mengembangkan potensi berpikirnya; 5) Cara berpikir yang dikembangkan dalam kegiatan belajar belum menyentuh domain afektif dan psikomotor. Alasan yang sering dikemukakan oleh para guru adalah keterbatasan waktu, sarana, lingkungan belajar, dan jumlah peserta didik per kelas yang terlalu banyak, dan 6) Evaluasi yang dilakukan hanya berorientasi pada produk belajar yang berkaitan dengan domain kognitif dan tidak menilai proses.

Sains dan teknologi manunggal menjadi budaya ilmu pengetahuan dan teknologi yang saling mengisi (komplementer), ibarat mata uang, yaitu satu sisinya mengandung. Hal tersebut di atas dikuatkan dengan hakikat Sains (the nature of Science) dan sisi yang lainnya mengandung makna teknologi (the meaning of technology). Dari uraian di atas dapat disimpulkan bahwa Ilmu Pengetahuan Alam adalah suatu disiplin ilmu yang mempelajari tentang konsep-konsep alam yang mengandung makna pengajuan pertanyaan, pencarian jawaban, pemahaman jawaban, penyempurnaan jawaban baik tentang gejala maupun karakteristik alam sekitar melalui cara-cara sistematis. Proses pembelajaran Ilmu Pengetahuan Alam menekankan pada pemberian pengalaman langsung agar menjelajahi dan memahami alam secara ilmiah.

\section{METODE PENELITIAN}

Metode yang digunakan dalam penelitian ini adalah deskriptif analitis melalui Penelitian Tindakan Kelas, yaitu studi yang digunakan untuk mengumpulkan data, mendeskripsikan, mengolah, menganalisa, menyimpulkan dan menafsirkan data sehingga memperoleh gambaran yang sistematis. Metode penelitian deskriptif analisis digunakan untuk mengetahui permasalahan dengan cara menguraikan secara rinci dan jelas, serta melakukan suatu analisis data dari permasalahan untuk memperoleh suatu kesimpulan dengan tujuan untuk menggambarkan dan menganalisis secara sistematis terhadap suatu fakta yang sifatnya faktual.

Objek sasaran dalam penelitian ini adalah SD Negeri Bantarjati 7. Menurut hasil pengamatan yang dilakukan peneliti melalui observasi kelas pada kelas V SD Negeri Bantarjati 7 semester 2 pada mata pelajaran Ilmu Pengetahuan Alam tentang materi gaya dan fungsinya. Peserta didik yang hasil belajarnya mencapai KKM hanya $30 \%$ dari nilai KKM yang ditetapkan yaitu 70. Hal ini memberikan gambaran bahwa hasil belajar peserta didik pada pembelajaran Ilmu Pengetahuan Alam tentang materi gaya dan fungsinya masih tergolong rendah dan perlu untuk diperbaiki. Dalam penelitian ini subjek yang diambil adalah peserta didik Kelas V SD Negeri Bantarjati 7 semester 2 yang berjumlah peserta didik. Pemilihan subjek ini berdasarkan pertimbangan bahwa subjek penelitian pada usia ini cara berpikirnya masih bersifat kongkrit, sehingga diperlukan adanya pembelajaran melalui perbuatan atau sering disebut dengan eksperimen. Berdasarkan pertimbangan ini model pembelajaran kooperatif Make a Match dapat membantu subjek penelitian untuk bisa menerapkan dalam kehidupan sehari-hari dan bisa samasama aktif dalam proses pembelajaran.

Pelaksanaan PTK ini dilaksanakan selama 6 bulan. Prosedur pengumpulan data dilakukan berdasarkan bentuk data yang diperoleh yaitu meliputi tes, observasi, dan catatan lapangan. 1). Tes dilakukan pada akhir tindakan, untuk mengetahui kesulitan yang dihadapi peserta didik dan juga untuk melihat tingkat pemahaman peserta didik dalam kegiatan pembelajaran. 2). Observasi, dilakukan untuk mengamati kegiatan kegiatan di kelas selama kegiatan pembelajaran, mengenai kesesuaian antara pelaksanaan tindakan dan perencanaan yang telah disusun, serta untuk mengamati partisipasi peserta didik khususnya subjek penelitian yang berkaitan dengan tindakan yang dilakukan oleh seorang guru dan seorang teman sejawat. 3). Catatan Lapangan, dilakukan untuk melengkapi data. Catatan Lapangan ini berisi tentang kegiatan secara objektif yang berkaitan dengan pembelajaran yang dilakukan oleh guru dan teman sejawat sebagai penunjuk adanya permasalahan dan dijadikan petunjuk dalam pelaksanaan langkah berikutnya. Prosedur tindakan kelas merupakan proses pengkajian melalui sistem yang berdaur ulang dari berbagai kegiatan pembelajaran yang terdiri atas empat tahap yang saling terkait dan bersinambungan. Tahap-tahap tersebut yaitu (1) perencanaan, (2) pelaksanaan, (3) pengamatan, dan (4) refleksi.

\section{HASIL DAN PEMBAHASAN}

Dari hasil pembelajaran menggunakan model pembelajaran kooperatif tipe Make a Match dan jawabanjawaban soal evaluasi yang diberikan, kemudian penulis menggunakan jawaban-jawaban tersebut untuk mengetahui apakah pembelajaran Ilmu Pengetahuan Alam menggunakan model pembelajaran kooperatif tipe Make a Match tersebut dapat meningkatkan hasil belajar peserta didik Kelas V Semester 2 SD Negeri Bantarjati 7, berikut ini adalah data yang diperoleh dari hasil pra siklus, siklus 1 dan siklus 2 .

Berdasarkan hasil penelitian selama dua siklus yang bertujuan untuk meningkatkan hasil belajar peserta didik pada materi gaya dan fungsinya, terlihat pada pelaksanaan siklus 1 dan siklus 2 telah menunjukkan peningkatan pada proses pembelajaran Ilmu Pengetahuan Alam tentang gaya dan fungsinya. Dengan menggunakan model pembelajaran kooperatif tipe Make a Match, Interaksi peserta didik dan guru di awal pelajaran diawali oleh guru dengan membuka pelajaran Ilmu Pengetahuan Alam dengan menggunakan model pembelajaran kooperatif tipe Make a Match sebagai titik tolak pelajaran. Kemudian guru mengarahkan dan menjelaskan bagaimana peserta didik belajar dengan baik. Kemudian pada saat proses belajar berlangsung, guru mengelola kelas secara interaktif, membimbing peserta didik, dan memotivasi peserta didik untuk aktif berperan dalam kegiatan pembelajaran. Pada akhir pembelajaran, guru bersama peserta didik menyimpulkan pelajaran yang telah dilaksanakan. Kemudian guru mengevaluasi peserta didik dengan memberikan soal-soal yang relevan dengan konsep. Berdasarkan hasil tersebut, dapat disimpulkan bahwa telah ada peningkatan aktivitas dan hasil belajar peserta didik 
pada pembelajaran Ilmu Pengetahuan Alam. Hal ini dapat dilihat dari peningkatan rata-rata nilai hasil belajar dari pra siklus, siklus 1 dan siklus 2 yang tersaji pada gambar 1 .

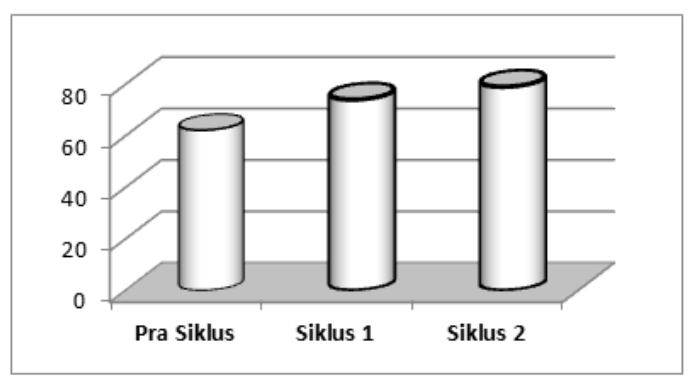

Gambar 1. Peningkatan Rataan Nilai siswa Tiap Siklus

Peningkatan rata-rata nilai peserta didik juga ditunjang oleh peningkatan nilai terendah dan tertinggi peserta didik setiap siklus seperti pada tergambar pada gambar 2.

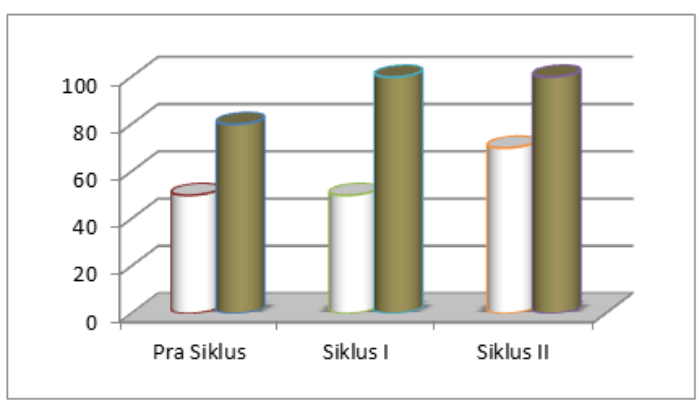

Gambar 2. Peningkatan Nilai Tertinggi dan Terendah Siswa Tiap Siklus

Dari gambar 2. di atas diperoleh bahwa nilai terendah pada pra siklus adalah 50 dan pada siklus 1 dengan nilai terendah 60 kemudian meningkat menjadi 70 pada siklus 2 . Selanjutnya nilai tertinggi pada pra siklus adalah 80 kemudian meningkat menjadi 90 pada siklus 1 dan pada siklus 2 meningkat menjadi 100. Hal ini menandakan bahwa model pembelajaran kooperatif tipe Make a Match cocok untuk diterapkan pada materi gaya dan fungsinya dalam pembelajaran Ilmu Pengetahuan Alam.

Selain peningkatan rata-rata nilai peserta didik model pembelajaran kooperatif tipe, Make a Match juga dapat meningkatkan persentase ketuntasan belajar peserta didik seperti tersaji pada gambar 3 .

Dari gambar 3 diperoleh bahwa pada pra siklus hanya $30 \%$ atau 12 peserta didik yang nilainya mencapai KKM yang ditetapkan, kemudian pada siklus 1 meningkat menjadi $67,50 \%$ peserta didik yang nilainya mencapai KKM, dan pada siklus 2 menjadi $100 \%$ peserta didik yang nilainya mencapai KKM. Berdasarkan temuan tersebut dan hasil diskusi dengan rekan sejawat, penulis melakukan perbaikan sebanyak 2 Siklus adapun langkah-langkah yang ditempuh adalah: 1). Guru telah melakukan upaya peningkatan peserta didik melalui model pembelajaran koopratif tipe Make a
Match pada pembelajaran Ilmu Pengetahuan Alam. 2). Melakukan kegiatan melalui pemberian contoh-contoh agar peserta didik lebih paham akan materi pelajaran Ilmu Pengetahuan Alam. 3). Memberikan latihan-latihan sesuai dengan waktu yang tersedia. 4). Dari pelaksanaan perbaikan pembelajaran selama 2 Siklus hasil evaluasi yang diperoleh peserta didik mengalami peningkatan proses pembelajaran Ilmu Pengetahuan Alam.

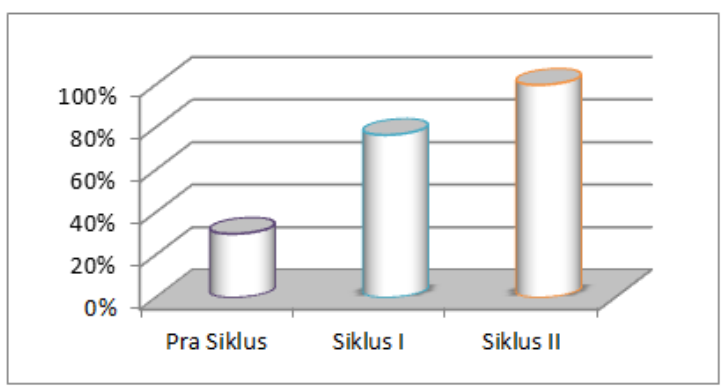

Gambar 3. Peningkatan Ketuntasan Belajar Siswa Tiap Siklus

Hasil refleksi siklus perbaikan ke 1 dan 2 ternyata menunjukkan adanya peningkatan dan perbaikan nilai peserta didik dalam proses pembelajaran Ilmu Pengetahuan Alam dari hasil refleksi proses pembelajaran Ilmu Pengetahuan Alam diketahui pada siklus 1 masih ada 13 orang peserta didik yang belum dapat memahami materi pelajaran Ilmu Pengetahuan Alam, waktu penggunaan model pembelajaran koopertif tipe Make a Match ada peserta didik yang tidak serius dimana mereka hanya ngobrol saja karena mereka belum memahami pembelajaran Ilmu Pengetahuan Alam.

Pada siklus 2 setelah diberikan latihan-latihan soa dan pemberian tugas di rumah, ternyata peserta didik yang tadinya masih kurang mampu sudah menunjukkan kemajuan pembelajaran Ilmu Pengetahuan Alam. Pada saat pelaksanaan model pembelajaran kooperatif tipe Make a Match diketahui seluruh peserta didik telah aktif dan mencapai nilai KKM.

Pada pelaksanaan pembelajaran dengan Model pembelajaran kooperatif tipe Make a Match seorang guru senantiasa dihadapkan dengan peserta didik yang memiliki kemampuan belajar yang berbeda, untuk itulah kita perlu memahami motivasi dalam diri peserta didik dan berusaha untuk mengelolanya dengan baik untuk membantu mereka berhasil mencapai tujuan tertentu.

Penerapan prinsip dan teknik mengajar seorang guru dalam penggunaan model pembelajaran kooperatif tipe Make a Match terhadap peserta didik di kelas haruslah dilakukan dengan memperhatikan ketentuan-ketentuan penggunaan model pembelajaran kooperatif tipe Make a Match.

Pembelajaran yang menyesuaikan dengan kondisi peserta didik dapat memberikan dampak yang baik terhadap peningkatan hasil belajar peserta didik. Hal ini menunjukkan bahwa perbaikan pembelajaran sangat diperlukan. Dari hasil pengamatan yang penulis lakukan, maka temuan penelitian di lokasi penelitian adalah sebagai berikut : 1). Dalam 
penggunaan model pembelajaran koopratif tipe Make a Match perlu disesuaikan antara materi dan kondisi peserta didik. 2). Penyediaan buku panduan dalam penggunaan model pembelajaran koopratif tipe Make a Match perlu disesuaikan dengan kapasitas peserta didik. 3). Dalam meningkatkan hasil belajar peserta didik pada pembelajaran Ilmu Pengetahuan Alam melalui penggunaan model pembelajaran koopratif tipe Make a Match perlu diupayakan peningkatan kompetensi guru.

\section{SIMPULAN}

Berdasarkan pada pembahasan kegiatan tindakan yang telah dilakukan oleh peneliti, maka dapat dirumuskan beberapa kesimpulan, diantaranya: 1). Hasil refleksi siklus perbaikan ke 1 dan 2 ternyata menunjukkan adanya peningkatan dan perbaikan nilai peserta didik dalam proses pembelajaran Ilmu Pengetahuan Alam dari hasil refleksi proses pembelajaran Ilmu Pengetahuan Alam diketahui pada siklus 1 masih ada 13 orang peserta didik yang belum dapat memahami materi pelajaran Ilmu Pengetahuan Alam, waktu penggunaan model pembelajaran koopratif tipe Make a Match ada peserta didik yang tidak serius dimana mereka hanya ngobrol saja karena mereka belum memahami pembelajaran Ilmu Pengetahuan Alam. 2). Diperoleh bahwa nilai terendah pada pra siklus adalah 50 dan pada siklus 1 dengan nilai terendah 60 kemudian meningkat menjadi 70 pada siklus 2. Selanjutnya nilai tertinggi pada pra siklus adalah 80 kemudian meningkat menjadi 90 pada siklus 1 dan siklus 2 meningkat menjadi 100 . Hal ini menandakan bahwa model pembelajaran koopratif tipe Make a Match cocok untuk diterapkan pada materi gaya dan fungsinya dalam pembelajaran Ilmu Pengetahuan Alam khususnya tentang gaya dan fungsinya. 3). Diperoleh bahwa pada pra siklus hanya $30 \%$ peserta didik yang nilainya mencapai KKM yang ditetapkan, kemudian pada siklus 1 meningkat menjadi $67,50 \%$ peserta didik yang nilainya mencapai KKM, dan pada siklus 2 menjadi $100 \%$ peserta didik yang nilainya mencapai KKM.

\section{REFERENSI}

[1] Y. Suchyadi and Nurjanah, 2018. Relationship between Principal Supervision in Increasing the Job Satisfaction of Private Junior High School Teachers in East Bogor District, J. Humanit. Soc. Stud., vol. 02, no. 01, pp. 26-29, 2018.

[2] Y. Suchyadi, 2017. Relationship between Work Motivation and Organizational Culture in Enhancing Professional Attitudes of Pakuan University Lecturers, J. Humanit. Soc. Stud., vol. 01, no. 01, 2017.

[3] R. Pertiwi and Y. Suchyadi, 2019. Implementasi Program Pendidikan Karakter Di Sekolah Dasar Negeri Lawanggintung 01 Kota Bogor, J. Pendidik. Pengajaran Guru Sekol. Dasar (JPPGuseda ), vol. 02, pp. 41-46, 2019.
[4] Lie, Anita. 2004. Cooperative Learning. Grasindo: Jakarta.

[5] Sugiyanto. 2009. Model Pembelajaran Inovatif. Panitia Sertifikasi Guru Rayon 13: Surakarta.

[6] Carin, A.A.1993. Teaching Modern Science, Sixh Edition. New York: Maxwell Macmilan International.

[7] Cain, Sandra E. dan Jack M. Evans. 1990. Sciencing: An Involvement Approach to Elementary Science Methods. Ohio: Merrill Publishing Company.

[8] Agus S, 2011. Ilmu Alam, Jakarta :Bumi Aksara,

[9] Depdiknas. 2008. Strategi pembelajaran MIPA. Jakarta: Direktorat Tenaga Kependidikan Direktorat Jenderal Peningkatan Mutu Pendidik dan Tenaga Kependidikan 